\title{
POSTMENINGITIS HEADACHE
}

\section{Case report}

\author{
André Palma da Cunha Matta', Márcia Cristina Antunes Ribas', \\ Pedro Ferreira Moreira Filho
}

\begin{abstract}
We report a case of a 18-year-old female patient that developed a migraine-like headache following an acute meningococcal meningitis. She had no previous history of recurrent headaches. The pain was intense, pulsatile and throbbing, typically unilateral, without aura. Its frequency increased during the following weeks and a prophylactic treatment with amitriptyline and atenolol was initiated. There was remission of the attacks.
\end{abstract}

KEY WORDS: headache, meningitis, migraine.

\section{Cefaléia pós-meningite: relato de caso}

RESUMO - Relatamos o caso de uma paciente de 18 anos, previamente hígida, sem história pregressa de cefaléia, que apresentou um quadro agudo caracterizado por febre, cefaléia holocraniana, sonolência, vômitos e sinais de irritação meníngea. Teve investigação laboratorial compatível com meningite meningocócica. Recebeu o tratamento adequado, evoluindo com regressão do quadro infeccioso. Desenvolveu, entretanto, episódios recorrentes de cefaléia pulsátil, sem aura, unilateral, de forte intensidade e acompanhada por náusea e fotofobia. A frequência dos episódios aumentou progressivamente até que se instituiu tratamento profilático com atenolol e amitriptilina, havendo remissão da dor.

PALAVRAS-CHAVE: cefaléia, meningite, migrânea.

The acute bacterial meningitis is usually associated with headache ${ }^{1}$. Three mechanisms explain this association: increased intracranial pressure, meningeal inflammation and the infectious process itself. Nevertheless, the natural history of the headache that begins during or immediately after an acute meningitis is not completely established. Some patients develop recurrent pain even after a complete resolution of the infectious process ${ }^{2}$. This type of headache is named postmeningitis headache ${ }^{2}$.

We report the case of a patient who is a girl of 18 years of age and she developed migrane-like headache after an acute bacterial meningitis. Informed consent was obtained from the patient.

\section{CASE}

A woman of 18 years of age, previously healthy, without previous history (and family history) of recurrent headaches, had an acute picture characterized by fever, diffuse headache, sleepiness, confusion, nausea and meningeal signs. The investigation by neuroimaging study and laboratory tests was compatible with meningococcal meningitis. Computerized tomography (CT) revealed a diffuse brain swelling and the Gram stain of the cerebro spinal fluid (CSF) revealed Gram-negative Diplococci. Later, it was confirmed by culture the Neisseria meninigitidis presence. She had the adequate treatment less than 24 hours after the beginning of the symptoms and the infectious picture got better, without any kind of motor, sensorial or cognitive sequelae. After 48 hours of treatment, the new CSF analysis already showed evident signs of improvement, with a significant regression of the initial pleocytosis and a decrease of pressure.

She developed, since the $10^{\text {th }}$ day of the treatment, recurrent episodes of pulsatile headache, that was unilateral, intense, accompanied by nausea and photophobia. The pain was not preceded by aura, and it was responsive to non-hormonal anti-inflammatories. In this occasion, she was submitted to a new CT, which showed a complete regression of the cerebral edema. A third lumbar puncture

Hospital Universitário Antônio Pedro - Universidade Federal Fluminense, Niterói RJ, Brazil: ${ }^{1} \mathrm{MD}$, Neurologist; ${ }^{2} \mathrm{PhD}$, Neurologist. Received 25 July 2006, received in final form 16 January 2007. Accepted 19 February 2007. 
revealed normal pressure and a total resolution of the infectious process. However, the frequency of headache attacks increased progressively on the following weeks, and a therapeutic test with naratriptan got success. At that time, it was instituted a prophylactic treatment with atenolol (50 $\mathrm{mg} /$ day) and amitriptyline ( $25 \mathrm{mg} /$ day).

The frequency of headache attacks decreased with time and a remission was achieved around five months after the resolution of the acute infection.

\section{DISCUSSION}

It was not enough the serious picture imposed by a meningeal infection, its long-term complications are equally serious and incapacitating. They include cognitive damage, epilepsy, motor deficit, sleep disorders, ataxia, deafness and hydrocephalus, just to mention some of them ${ }^{3-8}$.

Headache in the context of the acute phase of a bacterial meningitis is a very frequent phenomenon', but the headache as a possible long-term complication of a meningeal infection is not commonly described. The so-called postmeningitis headache is not frequently related in literature, although it is a nosologic entity mentioned in the international classification of headaches ${ }^{9}$. In the case we presented, pain characteristics resemble those described for the migraine without aura ${ }^{9}$. The good therapeutic response obtained with beta-blocker and tricyclic anti-depressant is also commonly found in migraine patients ${ }^{10}$.

It is accepted that the postmeningitis headache can have migrainous characteristics or not ${ }^{2}$. Ramadan, for example, described in 1994 an interesting case of cluster headache after a meningeal infection, that affected himself ${ }^{11}$. In order to better understand the postmeningitis headache, Neufeld and coworkers $^{2}$ followed 70 patients with meningitis' diagnosis aged between five and 78 years old, who did not presented other possible causes of headache (tumor, craniocerebral trauma, sinusitis and glaucoma). A comparison with a control group with similar characteristics (age and gender) was made. The assessment was made trough a detailed questionnaire that documented age, gender, date of the beginning of the headache, interval between the meningitis recovery and the beginning of the symptom, previous and familiar history of headache and its description. There was history of headache preceding the meningitis in 13 patients (19\%), with migrainous nature in eight of them. In the control group, 18 patients ( $26 \%$ ) had headache and it had characteristics of migraine in eight of them. After the meningitis, seven (54\%) of the 13 patients with previous headache related an increase in the intensity of pain. Headache of posterior installation to meningitis occurred in 19 patients and it was migrainous in six of them, increasing the total prevalence of headache in this group for $46 \%$ (32 in 70 patients). Among patients who developed the headache after the meningeal infection, the intensity varied from mild to moderate in 15 patients $(79 \%)$ and severe in four $(21 \%)$. In four of these patients $(21 \%)$ the headaches appeared in the first year after the meningitis.

From the pathophysiologic point of view, there is no satisfactory explanation for the appearance of postmeningitis headache. It has been speculated that it is related to the infectious process and the consequent dilation of cerebral vessels. This phenomenon would lead to a loss of the cerebrovascular autoregulation and to the appearance of recurrent episodes of pain ${ }^{11-13}$. Taking into consideration it is a bacterial meningitis, as in the case we describe, it is also commented that an adhesive arachnoiditis would develop after the acute phase and would cause the headache. Until this moment, we did not detect in our patient any clinical or radiological evidences of such event.

Despite the heterogeneity of the clinical presentation described in literature, in the current headache's classification, the chronic bacterial postmeningitis headache is considered a continuous and diffuse pain, that could be accompanied by vertigo and memory alterations ${ }^{9}$. Such characteristics of pain and accompanying phenomena were not observed neither in the case we relate nor in other cases described in literature.

In conclusion, although there are specific and predetermined criteria in the current headache's classification, many clinical presentations of headache have been reported under the designation of postmeningitis headache. It calls the attention the restricted literature about this theme, taking us to conclude that more works must be carried trough in order to better understand this disease.

\section{REFERENCES}

1. van de Beek D, de Gans J, Spanjaard L, Weisfelt M, Reitsma JB, Vermeulen M. Clinical features and prognostic factors in adults with bacterial meningitis. N Engl J Med 2004;351:1849-1859. Erratum in: N Engl J Med 2005;352:950. 
2. Neufeld MY, Treves TA, Chistik V, Korczyn AD. Postmeningitis headache. Headache 1999;39:132-134.

3. Schmidt H, Cohrs S, Hinemann T, et al. Sleep disorders are long-term sequelae of both bacterial and viral meningitis. J Neurol Neurosurg Psychiatry 2006;77:554-558.

4. Wang KW, Chang WN, Chang HW, Wang HC, Lu CH. Clinical relevance of hydrocephalus in bacterial meningitis in adults. Surg Neurol 2005;64:61-65.

5. Nobrega N, Weckx LL, Juliano Y. Study of the hearing loss in children and adolescents, comparing the periods of 1990-1994 and 1994-2000. Int J Pediatr Otorhinolaryngol 2005;69:829-838.

6. Taylor HG, Michaels RH, Mazur PM, Bauer RE, Liden CB.Intellectual, neuropsychological, and achievement outcomes in children six to eight years after recovery from Haemophilus influenzae meningitis. Pediatrics 1984;74:198-205.

7. Merkelbach S, Sittinger H, Schweizer I, Muller M. Cognitive outcome after bacterial meningitis. Acta Neurol Scand 2000;102:118-123.
8. Casella EB, Cypel S, Osmo AA, et al. Sequelae from meningococcal meningitis in children: a critical analysis of dexamethasone therapy. Arq Neuropsiquiatr 2004;62:421-428.

9. Subcomitê de Classificação das Cefaléias da Sociedade Internacional de Cefaléia. Classificação Internacional das Cefaléias. $2^{\mathrm{a}}$ edição. ICHDII. Tradução da Sociedade Brasileira de Cefaléia com autorização da Sociedade Internacional de Cefaléia. São Paulo: Editora Farma, 2004: $62-73$.

10. Sociedade Brasileira de Cefaléia. Recomendações para o tratamento profilático da migrânea: consenso da Sociedade Brasileira de Cefaléia. Arq Neuropsiquiatr 2002;60:159-169.

11. Ramadan NM. Postmeningitic cluster headache. Neurology. 1994;44: 2208.

12. Joseph R, Rose FC. Cluster headache and herpes simplex, an association? BMJ 1985;290:1625-1626.

13. DeAngelis LM, Payne R. Lymphomatous meningitis presenting as atypical cluster headache. Pain 1987;30:211-216. 